\title{
Strengthen the Role of Industry Associations and Promote the Development of Foreign Trade
}

\author{
Fanhua MENG, Meitian ZHAO \\ School of Business, North China Institute of Science and Technology, Sanhe, Hebei, China
}

\begin{abstract}
This thesis presents the idea that industry association under the framework of WTO in foreign trade management has more advantages than under the government, and points out that the industry associations play an important role in reducing transaction costs, standardizing enterprise behavior in foreign trade and in terms of dealing with international trade frictions. But the industry associations are not perfect and still have shortcomings in other areas. So in order to improve the role of industry associations in foreign trade ,it must be done to strengthen the construction of industry associations themselves, improve the man-agement system, establish a mechanism with the government, enterprises and industry associations linked to-gether; establish a system of university-industry cooperation and with the establishment of the international association network.
\end{abstract}

KEYWORD: Industry association; Environment of foreign trade; role; shortcoming; suggestions

\section{THE ADVANTAGES OF THE INDUSTRY ASSOCIATIONS IN FOREIGN TRADE MANAGEMENT}

\subsection{The overview of Trade Associations}

Industry Association is a nonprofit juridical association with business entities and natural persons in the same industry voluntarily involved in, a special intermediary organization between government and enterprises, thus a closer relationship between enterprises and the government has established. On one hand, as a self-discipline management organization of enterprises, industry association has many company members. They are familiar with the characteristics of the industry. Speaking of the enterprises, industry association is not only an administrative department, with the function of management, but also a right department to safeguard the interests of enterprises and the rights of enterprises and government departments, and to represent the communication and coordination mechanism. Therefore, industry associations can maintain the order of enterprise and standardize enterprise behavior. On the other hand, it can carry out the macroscopic intention of the government, safeguard the legal rights of enterprises in the competitive environment. Owing to the particularity of the status of the industry associations, they can undertake many affairs that governments and enterprises necessary but reluctant responsibilities and can better play its unique role.

\subsection{The advantages of industry associations}

What the WTO adjustment is the intervention of the government to each government members in terms of foreign trade, and the distortion degree of the policy of free trade. WTO rules have provisions for the government in the economic activities in the administrative functions and administrative procedures, the government can only exercise their functions and powers in the WTO legal framework. On the basis of WTO provisions, the members of the government's functional departments do not have the attribute of the enterprise, they cannot be directly involved in domestic and international market competition, the government can only be the makers of market rules rather than direct participants .At the same time, if the government establishes some encouraging policies ,they may be identified as subsidies by importing countries, thus adopt corresponding countervailing measures .Under the circumstance that in our country is facing more and more anti subsidy disputes case, this approach is obviously easier to handle. The industry association, however, is a special intermediary organization between government and enterprises, because they belong to the folk organization. The difference is in the domestic legal system, with its enterprise members competition and cooperation behavior being their object, directly under the jurisdiction of the industry association, the industry association is unlike the government that can accept multilateral trade rules, and can solve the participation in 
international trade and international trade disputes , and can directly or indirectly represent the identity of members in terms of these circumstances. There are particularly rules in the WTO about trade dispute settlement mechanism, industry association of different countries can pass the complaint directly to the WTO .Plus it is a common organization of the industry as a whole, but also the strength on behalf of enterprise members to solve a variety of international trade disputes. In the inter state disputes, industry associations can be a buffer, so that the government has more leeway. Therefore, compared with the government, the industry association and other industry organizations play a more important coordinating role.

\section{FUNCTIONS OF INDUSTRY SSOCIATIONS IN TERMS OF FOREIGN TRADE}

\subsection{Industry associations can reduce transaction cost of the enterprises}

Enterprises pay a certain cost to carry out foreign trade activities, such as collecting the status of the industry, the supply and demand of the international market competition pattern, the local national culture information, the collection and study of major foreign competitors strategy, looking for the member enterprises with international counterparts gap, getting informed of the legal situation in the other country, information needs, getting familiar with the WTO mechanism, collecting and provide relevant industry damages so on. However, with the participation of industry associations, the cost of information searching is reduced. Enterprise hand many such deals to industry associations to carry out, with the main work including legal services through industry associations, organizational exhibits, training, trade talks and providing enterprises with global business information and so on, with the purpose of helping enterprises develop export promotion activities. At present, with the increasing globalization of economic activities, information and knowledge, related association of countries are strengthened by high-tech means for the membership service efforts, in order to use the most economical method, timely transmission of relevant information to the members are needed, so that they can keep abreast of information on domestic and foreign markets, so the domestic and foreign markets can be effectively combined .For example, in recent years, the overseas institutions of America chamber of Commerce soared to 86 , which is to conform to the trend of globalization, the first of its "transformation". Similarly, National Chamber of Commerce organizations are constantly adjusting the organizational structure and business scope, improving for enterprises to participate in international competition and services.

\subsection{Industry associations can standardize enterprise behaviors in foreign trade}

Competition in the market will form a certain number of interest groups, in order to compete for limited resources, they take many inappropriate actions to win in the "vicious competition", this approach not only did not improve social welfare, but caused a lot of waste of resources and welfare losses. In terms of foreign trade, the circumstances mainly lie in hold down prices mutually in export enterprises, thus making the export commodity prices in our country significantly lower, the welfare of the native people who should have enjoyed the benefits getting lost in the "trade diversion" effects of the importing countries; On the other hand, they provide evidence to anti-dumping measures, anti subsidy and other trade protection measures against the importing countries. Therefore, to improve the environment for the development of foreign trade, we must realize that the orderly competition between enterprises and industry associations is of supreme importance. According to the relevant laws, industry associations should set up benign external coordination mechanism and internal mechanism of punishment to solve the conflicts of interests among enterprises in the industry, thus improving the overall quality of the industry, establishing the equal competition environment, so as to safeguard the interests of enterprises, reduce the international trade friction.

\subsection{Industry associations can play an important role in dealing with international trade friction}

At present, China is the world's most populous nation suffering from the trade remedy. According to the Ministry of Commerce statistics, from 2002 to December 24, 2013 , a total amount of 931 cases including anti-dumping, countervailing and safeguard measures, special safeguard investigations and other trade remedy cases, cases involving an amount of $\$ 77219000000$, relating to the metallurgy, chemical industry etc.. In 2014, a total of 22 countries and regions for the China export products initiated 97 trade remedy investigations. Among them, 61 anti-dumping, countervailing safeguard measures 14, 22, involving a value of $\$ 10490000000$. In response to the "two against one", the most important thing is to actively respond to, rather than passively waiting for. Responding to the need to do a lot of work and collect a lot of information, industry associations will use its professional advantages to coordinate and organize more efficiently.

Because of the ability of technological innovation, product life cycle and the influence of actors such as talent of China's export products will still give priority to with resource intensive and labor-intensive products, these product similarity indexes are high, the international market competition is unusually intense. Therefore, in the 
next period of time the anti-dumping investigation will still be the main form of the enterprises of our country encountering foreign trade remedies, and the number of anti-dumping and countervailing investigate the merger increases, the occurrence of such a situation not only increases the difficulty to improve there responding, responding to cost, and may trigger a "Domino" effect, will pose a threat to the healthy development of China's industry, seriously affected the development of China's foreign trade.

To cope with the international trade friction, industry associations should use its professional advantages to coordinate and organize more efficiently. In general, after receiving anti-dumping complaint investigations, the importing country should send questionnaires to the producers and distributors, requesting relevant production volume, cost, the domestic price, export volume, export prices and a series of data. If the investigated party doesn't actively provide information, it will lose the opportunity to defend for himself. Industry associations can represent the enterprises to better cooperate with the investigation, providing a complete information and statistical data they requested, providing convenience for verification, so that the surveyed party can comprehensively and truly understand the industry, thus making a fair, reasonable decision. At the same time, the industry association can guide the development of the industry, adjust the industrial structure, promote the upgrading of the transformation of enterprises, play a positive role in enhancing enterprise competitive status and so on, thus reducing trade frictions.

\section{PROBLEMS IN CHINA'S INDUSTRY ASSOCIATIONS}

\subsection{Unclear status, limited function space}

On the one hand the government hopes that the industry association can be an auxiliary tool management, and through the transfer of part of the functions of the government, making their industry management rights "legitimately" extended; on the other hand, most of the industry association would like to become a manager, to organize and manage its member enterprises, while neglecting the point that it should first of all on behalf of the enterprise interests. The status of trade associations is not clear, which lead to the limited function space, which is mainly reflected in the government still controlling the development of the industry and directly control the behavior of the enterprise policy and administrative means, such as a large number of administrative examination and administrative approval. This forced the enterprises making effects on the government to seek survival and development opportunities, so that the industry association is in an embarrassed condition that it may not be necessary. In addition, the enterprise itself is not fully aware of the role and importance of the industry association, they do not know how to use the industry associations to protect their own interests.

\subsection{Unreasonable internal operation mechanism, imperfect mechanism}

Although the industry association may be effective in the coordination of prices, standardizing enterprise behaviors, avoiding vicious competition, however, we should see the lace of corresponding power in our province, many industry associations, without punishment nor the means of reward. Some industry associations failed to adhere to the "openness, fairness, justice" principle in the performance of the industry management functions. At the same time, the industry self-discipline supervision is not enough, the self regulatory measures are mere formality. Our industry association only has the right to inform criticism and the suggestions of punishment, which is not enough a deterrent to offenders.

\subsection{Without a wide range of association with the outside world, inadequate information functions}

The function of industry association is single, and they don't have adequate association with other social groups, thus cannot provide sufficient information for the enterprises. China's industry association is more of a coordinating role among enterprises, unlike Europe and the United States Association, which are to promote products as their main business. In recent years, China's Industry Association has made some progress in these areas, but due to its rare popularity, and inadequate practical activities, their attractivity is not enough; compared with foreign Trade Associations, the representatives of industry associations in China are much less than other countries and regions, and there are only a few Chinese International Chamber of commerce of International trade association.

\section{COUNTERMEASURES TO IMPROVE THE FUNCTION OF TRADE ASSOCIATION IN FOREIGN TRADE}

In order to bring industry associations into full play in improving trade development environment in Hebei Province, we should not only strengthen the self construction of trade association, but also need to play a bridge role among enterprise and government, research institutes and international market.

\subsection{Strengthen the construction of industry association itself and improve the management system}

In order to further improve the trade environment, industry associations must strengthen self 
construction, perfection and innovation of management system. First of all, it should take measures on the semi official trade association for transformation and actively supporting the development of folk trade association. Because of the unclear concept and role positioning, the service and communication function is blocked, therefore need to transform reconstruction mechanism and function. They should further support and promote the folk association, making it rapidly grow. Secondly, they should establish the industry association market operation mode. In order to make industry association functional, we need to establish a stable fund. Currently, the association should mainly use the market to raise funds for construction, a part of which coming from the membership dues of the unit, but primarily by charging high quality service fees. To achieving this, industry associations should strengthen information gathering and dissemination functions, strengthen talent reserve and strengthen the attraction of business enterprises.

\subsection{Establish and form a linkage mechanism of three-in-one, which involved of government, enterprise and industry associations}

The so-called "three-in-one" linkage mechanism refers to the circumstance that in terms of improving the environment of trade, government, enterprises, industry associations are carrying out their duties, and rely on each other, unifying closely and play together more. First of all, all three are separated and play different roles, the establishment of international economic coping mechanism from the perspective of micro, meso and macro three levels. At the micro level, enterprises should inctease products internationally competitive, thus changing the trading situation based on the price competition. At the meso level, we should strengthen the building of Industry Association, assume its responsibilities and play a positive role. At the macro level, the provincial government should issue a series of policies to support industry associations, they can transfer the incentive measures to enterprises to industry associations, let them carry the workload instead. On the one hand, it can improve influence and authority of the industry associations, on the other hand, it can reduce the foreign trade friction. Secondly, the three is unified, in foreign trade, the three should make joint actions.

\subsection{The establishment of cooperative trade association system}

There is a lot of industry experts and influential businessmen associations in the industry, we should make use of these valuable human resources, and promote exchanges and cooperation of enterprises, universities and research institutions, coordinate the relationship between them, transfer the related research achievements into information resources and make contributions to the development of enterprises. The three are closely linked, we should make them play their information sharing function, transfer the technology innovation information to different enterprises, so that the enterprises can be commonly developed and thus enhance the competitiveness of the whole industry. This will not only help enterprises to save cost, but also change the situations where college science research institutions divorce themselves from the actual condition. At the same time, finance and economics colleges have experts on trade, investment and related legal rules such as WTO rules and regulations and trade policies and laws in the world's major countries.

\subsection{Establish international network of contacts of industry association}

Nowadays, with the development of globalization, not only should enterprises carry out the strategy of "going out", but industry associations should do the same. We should establish the representative offices in other countries as well; actively set up fixed connection with the chamber of Commerce in key countries (regions) and other peer organizations, lawyer organizations; actively participate in annual meetings of International Trade Association; establish a group of international trade association organizations and build extensive international network of contacts, only in this way can we provide a full range of international information for the enterprises, really exert the function of information service of industry association.

Taking part in the main exhibitions in international trade is the main way to expand the trade of enterprises in our country. For some small and medium-sized enterprises, the cost of attending overseas exhibitors is pretty high and the enthusiasm of enterprises is not enough. According to international experience, the industry association can use its international network of contacts to guide enterprises to the industry as a unit to participate in large-scale professional exhibition, which can make the enterprises have access to a wide range of potential partners, in order to gain a large scale of benefits.

\section{REFERENCES}

[1] Haixia Xie, Xiaohong Duan. The role of industry associations in the international trade. China inspection and quarantine, 2009(10).

[2] Feng Cao. Study on the role of industry associations in dealing with international trade friction. University of International Business and Economics, 2011.

[3] Jingjing Jin. Problems and Countermeasures of China's Industry Association.2012.

[4] Hongqing Liu, Jie Hou, Lingfang Yan. Industry Associations - The mainstay of the anti-dumpings waiting to be discovered. Theory of Jiangsu, 2006(04). 